\title{
Examination Of The Relationship Between Financial Development And Economic Growth: Case Of Turkey
}

Özge BOLAMAN AVCI*

\section{ABSTRACT}

The relationship between economic growth and financial development is investigated within the framework of this study in which financial development is examined under three sections including banking development, stock market development and debt market development. Examination is made by using quarterly data of Turkey for the period 2003Q12016Q1. At the end of study, a unidirectional relationship is found from stock market development to economic growth which validates "Supply Leading Hypothesis". From the perspective of banking development and debt market development, way of causality relationship validates "Demand Following Hypothesis".

Keywords: Financial Development, Economic Growth, Banking, Stock Markets, Debt Markets.

Jel Classification: G2, 043.

Finansal Gelişme Ve Ekonomik Büyüme Arasındaki İlişkinin İncelenmesi: Türkiye Örneği

\section{$\ddot{O Z Z E T}$}

Bu çalışma kapsamında bankacılık sektörünün gelişimi, pay piyasasının gelişimi ve borçlanma piyasasının gelişimi olarak üç alt başlı altında incelenen finansal gelişme ile ekonomik büyüme arasındaki ilişki incelenmiştir. İnceleme 2003 yılının ilk çeyreği ile 2016 yılının ilk çeyreği arasındaki dönemi kapsayacak şekilde çeyreklik Türkiye verisi kullanılarak gerçekleştirilmiştir. Çalışmanın sonucunda "Arz Öncüllü Hipotez" e uygun olarak pay piyasasının gelişiminden ekonomik büyümeye doğru tek yönlü nedensellik ilişkisi tespit edilmiştir. Bankacılık sektörünün büyümesi ve borçlanma piyasasının gelişimi açısından nedensellik ilişkisi "Talep Takipli Hipotez" $i$ destekler şekildedir.

Anahtar Kelimeler: Finansal Gelişme, Ekonomik Büyüme, Bankacılı, Pay Piyasaları, Borçlanma Piyasası.

JEL Sinıflandırması: G2, O43.

\footnotetext{
* Dr. Özge Bolaman Avcı, Pamukkale University, Faculty of Economics and Administrative Sciences, Department of International Trade and Finance, obolaman@ pau.edu.tr.
} 


\section{INTRODUCTION}

There is a growing body of literature examining the relationship between financial development and economic growth. Number of studies which examine mentioned relationship has increased after Great Depression when collapse of financial system is accompanied by real economic activity struck. Afterwards Fisher (1933) has argued that severity of economic downturn resulted from poorly performing financial markets.

According to Schumpeter financial intermediaries play a pivotal role in economic development since they choose which firms to use society's savings (Beck et al, 2000:262). Based on this view, financial institutions influence economic progress by affecting allocation of savings. Schumpeter, who asserts that banking system is critical in economic growth, also states that well-functioning banks spur technological innovation by identifying and funding productive investments. Other authors, who see finance as a critical element of growth, are Goldsmith (1969), Mc kinnon (1973), Shaw (1973), King and Levine (1993). On contrary in his famous paper Robinson (1952) argues that "where enterprise leads finance follows". From another perspective Nobel laureate Robert Lucas (1988) asserts that economists badly overstress role of financial system in determination of economic growth. A more recent study that is prepared by Miller (1998) specifies that "the idea that financial markets contribute economic growth is a proposition too obvious for serious discussion."

In a world where there is perfect competition and no market frictions exist, there would be no need for financial intermediation. In such a theoretical world individuals could invest in projects and firms with payoffs that are optimal given individual's time horizon and preferences (Becsi and Wang, 1997: 47). Nonetheless there are market frictions in the real world. In a case when market conditions are less than perfect, economic exchange becomes costly and if it is sufficiently costly it may not occur at all (Khan and Senhadji, 2000: 3). Here financial intermediaries comes into the stage and make these exchanges affordable.

Although there is not a single model which fully explains why financial intermediaries exist, frictions that give rise to financial intermediaries can be examined under two categories: technological frictions and incentive frictions. Due to technological frictions, individuals can not benefit from economies of scale. These frictions can be reduced by financial intermediaries. Individual investors could be too small to afford securities issued by firms. Via fund-pooling mechanism financial intermediaries give those individuals opportunity to involve in large investment projects and by this way they have access to economies of scale. Financial intermediaries also make riskier investments available to small savers via risk pooling mechanism. Another benefit provided by intermediaries to individual investors is liquidity management. Financial intermediaries not only reduce transaction costs but also collect large amounts of information at a lower cost. By this way they enhance resource allocation and accelerate growth. 
Incentive frictions take place since information is costly and asymmetrically distributed. Asymmetric information creates adverse selection and moral hazard problems. According to Galetovic (1994) limited liability creates divergent incentives between lenders and borrowers. Here financial intermediaries maintain some tasks: They collect inside information about borrowers; screen, monitor and influence their actions. These services are provided efficiently by intermediaries since they benefit from scale economies in screening, monitoring and information collection. Moreover adverse selection and moral hazard problems are mitigated by financial intermediaries.

Two hypotheses are developed by Patrick (1966) who attempt to associate economic growth and financial development. These are demand-following hypothesis and supplyleading hypothesis. According to demand following hypothesis the more rapid growth rate of real national income, the greater will be the demand for external funds and financial intermediation. This is the case since firms will be less able to finance expansion from internally generated depreciation allowances and retained earnings under most circumstances (Patrick, 1966: 175). Nonetheless it is also specified that several obstacles and imperfections in the operation of market mechanism in underdeveloped markets may create an inadequate demand-following response by financial system. According to supply-leading hypothesis of Patrick (1966), which bases on the view of Schumpeter (1912), financial development causes economic growth by allocating resources to more productive industries. Two functions of "Supply-Leading" are mentioned by the author: Transferring resources from traditional industries to modern industries and stimulating an entrepreneurial response in these modern industries. Based on Al- Yousif (2002) financial intermediaries contribute economic growth through two channels: First by raising efficiency of capital accumulation and in turn marginal productivity of capital, second by raising savings rates and thus investment rate.

King and Levine (1993) define level of financial development as a good predictor of economic growth. Consistently, according to Levine (1999) cross country differences in financial sector explain a meaningful proportion of cross-country differences in long run economic growth rates. Parallel to Levine (1999), Loayza and Ranciere (2005) state that financial development lead to higher economic growth in the long run since it entails a deepening of markets and services which channel savings to productive investments and allow risk diversification. Nonetheless authors also points out that economic growth may suffer from financial fragility which characterizes maturing systems. According to author elements of financial fragility like systemic banking crises, cycles of booms and busts and financial volatility may hurt economic growth until maturity is reached.

Beside debates about the relationship between financial development and economic growth, comparative importance of bank-based and market-based financial systems have been discussed by financial economists. Proponents of bank-based systems assert that information is transmitted to investors at large in highly liquid markets and this creates a free rider problem which dissuades individual investors from devoting resources toward researching 
firms. Banks may mitigate potential disincentives by privatizing the information they acquire. They could make investments without revealing their decisions immediately in public markets which create incentives to research firms, managers and market conditions (Levine, 2005:882). Corporate control, which may not be exerted by individual investors who are less informed, is exerted by banks. By this way possibility of golden parachutes, poison pills is mitigated. On the other hand proponents of market-based systems highlight the weaknesses of bank-based systems. From this outlook big banks encourage firms to undertake conservative investment strategies and extract large rents from firms (Levine, 1999: 116). As a result not only corporate profits decrease but also incentives for new and innovative products are reduced. Based on Arestis et al (2001) stock markets facilitate investment through encouraging specialization, acquisition and dissemination of information and decreasing cost of mobilizing savings. Author also specifies that well-developed stock markets enhance corporate control by mitigating principle agent problem by aligning interests of managers and owners. Moreover since stock markets enable investors to buy/sell equities quickly, financial assets traded in those markets become less risky. Stock markets also provide firms easy access to capital through equity issues. Less risky assets and easy access to capital markets improves capital allocation which is an important channel of economic growth (Arestis, 2001:18). An IMF Working Paper written by Abbas and Christensen (2007) has highlighted the increasingly important role of domestic debt markets in supporting economic development.

\section{LITERATURE REVIEW}

King and Levine (1993), who have studied the empirical link between a range of indicators of financial development and economic growth, has found indicators of level of financial development (size of financial intermediary sector relative to GDP, importance of banks relative to central bank, percentage of credit allocate to private firms and ratio of credit issued to private firms to GDP) correlated with growth, rate of physical capital accumulation and improvements in the efficiency of capital allocation. Moreover it is concluded that predetermined components of financial development indicators predict subsequent values of economic indicators.

Rajan and Zingales (1998) has asked if industrial sectors which are relatively more in need of external finance develop faster in countries with more developed financial markets. Authors conclude that it is the case for a large sample of countries over the 1980's. In the same year Levine and Zervos (1998) has questioned if well-functioning stock markets and banks promote long run economic growth. At the end of the study stock market liquidity and banking development is found positively correlated with contemporaneous and future rates of economic growth.

After two years from the study of Levine and Zervos, Khan and Senhadji (2000) have examined the relationship between financial development and economic growth by using data 
of 159 countries for the period 1960-1999. In consistence with literature a statistically significant positive relationship is found between financial depth and growth. A similar study is prepared by $\mathrm{Zu}$ (2000) who has investigated the effects of financial development on domestic investment and output by using data of 41 countries for the period 1960-1993. At the end of this study author has found strong evidence showing that financial development is important to growth and investment is an important channel through which financial development affects growth.

Al-Yousif (2002) has investigated same relationship by using data of 30 developing countries for the period 1970-1999. Empirical results indicate that financial development and economic growth are mutually causal. Authors have highlighted the point that since economic policies are country specific and their success depends on the efficiency of institutions implementing them, relationship between financial development and economic growth cannot be generalized across countries. In subsequent year, Levine (2003) has reviewed recent relevant literature and reach three conclusions: Firstly countries that have better-developed financial systems tend to grow faster. Both stock market liquidity and size of banking system are found positively related with economic growth. Secondly simultaneity bias does not seem to be cause of this result. Lastly better functioning financial systems ease external financing constraints which impede firm and industrial expansion.

Ünalmış (2002) has investigated the direction of causal relationship between financial development and economic growth in Turkey by using data of 1970-2001. Empirical results show that causality runs from financial development to economic growth in the short run. Nonetheless in the long run bidirectional causality is detected between co integrated series within the context of VECM. A similar study is written by Çetintaş and Barışık (2003) who has examined the relationships between banking sector, stock market development and economic development for the years 1989-2000 by using cointegration tests and Granger Causality Tests. Results show that both banking sector development and stock market development are positively related with economic development. Furthermore it is also found that banking sector development affects economic growth indirectly via stock market development. This validates the case that stock market is not a substitute, but rather complementary of banking sector.

Kandir et al. (2007) has examined the relationship between financial development and economic growth by using quarterly data for the period 1988-2004. Authors, who have detected cointegration relationship between variables, implement causality test via VECM. At the end of the study authors state that economic growth causes financial development in the short run and in the long run. Results are consistent with demand following hypothesis. Same relationship is also examined by Yücel (2009) who has used monthly data for the period 1997 M1-2007M8. In this study a latent variable is constructed by combining four dimensions of stock market development via principle components method. Results indicate that stock market development has a positive effect on economic growth. 
Öztürk et al. (2011) has implemented a panel causality analysis for nine developing countries including Turkey for the period 1992-2009 in order to examine the relationship between financial development and economic growth. Findings of that study show that economic growth lead to development of financial system which validates the demand following hypothesis of Patrick (1966). In the same year, Uğur and Küçükkaya (2011) has prepared another paper in which they construct a comprehensive financial development index by using principal component analysis. At the end of the empirical analysis authors fail to find any long run causality.

Ak et al. (2016) has also examined the relationship between financial development and economic growth by using yearly data of Turkey for the period 1989-2011. In this study where authors have developed a financial development index, Toda Yamamoto test is applied. At the end of this study a unidirectional relationship is found from economic growth to financial development. In other words, empirical results are in consistence with demand following hypothesis.

\section{DATA AND METHODOLOGY}

In the empirical part of this study the relationship between financial development and economic growth will be examined. Financial development will be investigated under three sections: Banking development, stock market development and debt market development. In the empirical analyses total credit to private non-financial sector, market capitalization of Borsa Istanbul and traded value of debt securities market is used as proxies for banking development, stock market development and debt market development respectively. On the other hand expenditure based GDP (fixed) is used as a proxy of economic growth. Logarithmic forms of all variables are used in quarterly frequency for the period between 2003Q1-2016Q1.

In the empirical part firstly existence of unit root is questioned for all variables by using ADF and Philips Perron tests. After then, Zivot Andrews Unit root test which takes structural breaks into account will be applied. In the next step causality relationship will be questioned by using Granger Causality Test which bases on VAR model. Results of unit root tests are given in table 1. 
Table 1. Unit Root Test Results

\begin{tabular}{|c|c|c|c|c|}
\hline & \multicolumn{2}{|c|}{$\mathrm{ADF}$} & \multicolumn{2}{|c|}{ Philips Perron } \\
\hline & Level & $\begin{array}{c}\text { First } \\
\text { Difference }\end{array}$ & Level & $\begin{array}{c}\text { First } \\
\text { Difference }\end{array}$ \\
\hline LNCRED & $\begin{array}{c}n_{u}- \\
3.903249 * \\
{[-2.922449]}\end{array}$ & 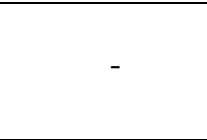 & $\begin{array}{c}\eta_{\mu}-5.852328^{*} \\
{[-2.919952]}\end{array}$ & - \\
\hline & $\begin{array}{c}\eta_{x}-4.381507^{*} \\
{[-3.504330]}\end{array}$ & - & $\begin{array}{l}\eta_{t}-6.390348 * \\
\quad[-3.500495]\end{array}$ & - \\
\hline LNCAP & $\begin{array}{c}\eta_{\mu}-5.736348^{*} \\
{[-2.919952]}\end{array}$ & - & $\begin{array}{c}\eta_{u}-5.672033^{*} \\
{[-2.919952]}\end{array}$ & - \\
\hline & $\begin{array}{c}\eta_{\tau}-5.932601 * \\
{[-3.500495]} \\
\end{array}$ & - & $\begin{array}{c}\eta_{t}-5.843307^{*} \\
{[-3.500495]}\end{array}$ & - \\
\hline LNDEBT & $\begin{array}{c}\eta_{\mu}-7.520285^{*} \\
{[-2.922449]} \\
\end{array}$ & - & $\begin{array}{c}\eta_{u}-15.13435^{*} \\
{[-2.919952]}\end{array}$ & - \\
\hline & $\begin{array}{c}\eta_{x}-7.780267^{*} \\
{[-3.504330]}\end{array}$ & - & $\begin{array}{c}\eta_{\tau}-25.38767 * \\
{[-3.500495]} \\
\end{array}$ & - \\
\hline LNGDP & $\begin{array}{c}\eta_{\mu}-3.255935^{*} \\
{[-2.926622]}\end{array}$ & - & $\begin{array}{c}\eta_{u}-11.77042 * \\
{[-2.919952]}\end{array}$ & - \\
\hline & $\begin{array}{c}\eta_{\tau}-3.245174 \\
{[-3.510740]}\end{array}$ & $\begin{array}{r}\eta_{\tau}-3.810648^{*} \\
{[-3.526609]}\end{array}$ & $\begin{array}{c}\eta_{\tau}-12.42556^{*} \\
{[-3.500495]}\end{array}$ & - \\
\hline
\end{tabular}

$\eta_{\tau}$ and $\eta_{\mu}$ refer to the test statistics with and without trend, respectively. $*$ denote rejection of null hypothesis at 5\%. Numbers in brackets are Mc Kinnon critical values for \% 5

As it is obvious in Table 1, logarithmic forms of all variables are stationary at level based on not only ADF test but also Philips Perron Test. LNGDP which is non-stationary with trend based on ADF test is the only exception. Nonetheless it is stationary with and without trend according to Philips Perron test. In the next step Zivot Andrews Unit Root Test which takes structural breaks into account will be implemented. In this study model $\mathrm{C}$ which is the least restrictive one is used. 
Table 2. Results of Zivot Andrews Test

\begin{tabular}{|l|c|c|}
\hline \multicolumn{1}{|c|}{ Variable } & Break Date & Ziwot Andrews t-stat \\
\hline LOGCRE & $2006 \mathrm{Q} 3$ & -4.915253 \\
& & {$[-5.08]$} \\
\hline LNDEBT & $2008 \mathrm{Q} 3$ & -9.216884 \\
& & {$[-5.08]$} \\
\hline LNCAP & $2009 \mathrm{Q} 2$ & -6.992748 \\
& & {$[-5.08]$} \\
\hline LNGDP & $2009 \mathrm{Q} 4$ & -4.704935 \\
& & {$[-5.08]$} \\
\hline
\end{tabular}

Table 2 proves existence of unit root in LOGCRE and LNGDP. Structural breaks are observed in third quarter of 2006 and fourth quarter of 2009 for LOGCRE and LNGDP respectively. Since all variables are not non-stationary, cointegration tests could not be implemented. Because of that reason causality relationship between economic growth and each of financial development components will be examined by using Granger Causality Test which bases on VAR model. Appropriate lag number, at which there is no autocorrelation and heteroscedasticity and where stability condition is met, is determined according to Akaike and Schwarz information criteria. Appropriate lag numbers are 4, 4 and 3 for LNCRED, LNCAP and LNDEBT respectively.

Table 3. Results of Granger Causality Test

\begin{tabular}{|c|c|c|c|}
\hline & \multicolumn{3}{|c|}{ Test Statistics } \\
\hline Null Hypotheses & Chi-square & Probability & Conclusion \\
\hline $\begin{array}{c}\text { LNCRED does not } \\
\text { Granger Cause LNGDP }\end{array}$ & 7.615815 & 0.1067 & Fail to Reject Ho \\
\hline $\begin{array}{c}\text { LNGDP does not } \\
\text { Granger Cause LNCRED }\end{array}$ & 14.86611 & 0.0050 & Reject Ho \\
\hline $\begin{array}{c}\text { LNCAP does not Granger } \\
\text { Cause LNGDP }\end{array}$ & 27.43132 & 0.0000 & Fail to Reject Ho \\
\hline $\begin{array}{c}\text { LNGDP does not } \\
\text { Granger Cause LNCAP }\end{array}$ & 2.834668 & 0.5859 & Fail to Reject Ho \\
\hline $\begin{array}{c}\text { LNDEBT does not } \\
\text { Granger Cause LNGDP }\end{array}$ & 5.957081 & 0.1137 & Reject Ho \\
\hline $\begin{array}{c}\text { LNGDP does not } \\
\text { Granger Cause LNDEBT }\end{array}$ & 10.00322 & 0.0185 & \\
\hline
\end{tabular}


Table 3 has indicated that there is a unidirectional causality from economic growth to banking development and debt market development. From perspective of stock market, direction of the relationship is in the opposite way. Unidirectional causality exists from stock market development to economic growth. From perspective of banking development and debt market development, results validates "Demand Following Hypothesis" of Patrick (1966). On the other hand unidirectional causality relationship which exists from stock market development to economic growth validates "Supply Leading Hypothesis" of Patrick (1966).

\section{CONCLUSION}

The relationship between financial development and economic growth is a widely discussed phenomenon in the existing literature most of which focus on developed markets. Studies which examine same phenomenon for developing markets are started to be written later than those which investigate developed markets since financial sector has developed later in developing markets. Even though stock markets have a long history in developed markets, Turkish stock market has been established in 1986. Despite the growth banking sector and debt market have experienced in Turkey, they are still smaller compared to developed markets. In this study the relationship between financial development and economic growth is analyzed for Turkey by using data between 2003Q1-2016Q1. Financial development is examined under three sections: Banking development, stock market development and debt market development. By this way effect of each component on economic growth is aimed to be analyzed individually. In examination of causality relationship, a unidirectional relationship is found from stock market development to economic growth. That result is consistent not only with Ünalmış (2002) who has found a unidirectional causality from financial development to economic growth but also with Yücel (2009). This case is consistent with "Supply Leading Hypothesis" of Patrick (1966). Results indicate that financial development has to be sustained in order to spur economic growth. Here it is essential to implement policies which promote investment. In order to encourage savers to hold their savings in the form of financial assets rather than unproductive tangible assets incentives should be induced. Another critical point is the construction of legal and institutional framework. From another perspective, unidirectional causality relationship exists from economic growth to both banking development and debt market development. That case is in consistence with "Demand Following Hypothesis" of Patrick (1966) which asserts that the more rapid the growth of real national income, the greater will be the demand for external funds and financial intermediation since under most circumstances firms will be less able to finance expansion from internally generated depreciation allowances and retained profits. That result is consistent with both Öztürk et al (2011) and Ak et. al (2016). 


\section{REFERENCES}

Abbas, S.M.A. and Christensen, J.E. (2007) "The Role of Domestic Debt Markets in Economic Growth: An Empirical Investigation for Low-Income Countries and Emerging Markets", IMF Working Paper.

Ak, M.Z., Altıntaş, N. and Şimşek, A.S. (2016) “Türkiye'de Finansal Gelişme ve Ekonomik Büyüme İlişkisinin Nedensellik Analizi”, Doğuş Üniversitesi Dergisi, Vol.17, No.2, p.151-160.

Al-Yousif, Y.K. (2002) "Financial Development and Economic Growth Another Look at the Evidence from developing countries", Review of Financial Economics, Vol.11, p.131150.

Arestis, P., Demetriades, P.O. and Luintel, K.B. (2001) "Financial Development and Economic Growth: The Role of stock markets", Journal of Money, Credit and Banking, Vol.33, No.1, p.16-41.

Beck, T., Levine, R., and Loayza, N. (2000) "Finance and Sources of Growth", Journal of Financial Economics, Vol.56, p.261-300.

Becsi, Z., Wang, P. (1997) "Financial Development and Growth", Federal Reserve Bank of Atlanta.

Çetintaş, H. and Barışık, S. (2003) "Türkiye'de Bankalar, Sermaye Piyasası ve Ekonomik Büyüme: Koentegrasyon ve Nedensellik Analizi”, Vol.25-26, p.1-16.

Galetovic, A. (1994) "Finance and Growth: A Synthesis and Interpretation of The Evidence", Board Governors of Federal Reserve Sytem International Finance Discussion Papers, Number 477, August 1994.

Kandır, S. Y., İskenderoğlu, Ö. And Önal, Y. B. (2007) "Finansal Gelişme Ekonomik Büyüme Arasındaki İlişkinin Araştırılması”, Çukurova Üniversitesi Sosyal Bilimler Enstitüsü Dergisi, Vol.16, No. 2, p.311-326.

Khan, M., Senjandi, A. (2000) "Financial Development and Economic Growth: An Overview", IMF Working Paper.

King, R.G. and Levine, R. (1993) "Finance and Growth: Schumpeter might be right", The Quarterly Journal of Economics, Vol.108,No3,p.717-737.

Levine, R (1999) “Financial Development and Growth: Where Do We Stand?”, Estudios de Economia, Vol.26, No.2, p.113-136.

Levine, R. (2005) "Handbook of Economic Growth”, Vol.1A, Elsevier.

Loayza, N. and Ranciere, R. (2005) "Financial Development, Financial Fragility, and Growth", IMF Working Paper, August 2005.

Lucas, R.E. (1988) "On the Mechanics of Economic Development", Journal of Monetary Economics, Vol.22, p.3-42.

Miller, M.H. (1998) "Financial Markets and Economic Growth", Journal of Applied Corporate Finance, Vol.11, p.8-14. 
Öztürk, N., Darıc1, H. and Kesikoğlu, F. (2011) "Ekonomik Büyüme ve Finansal Gelişme İlişkisi: Gelişmekte Olan Piyasalar İçin Bir Panel Nedensellik Analizi”, Marmara Üniversitesi, İ.̇̇.B.F. Dergisi, Cilt XXX, s.53-69.

Patrick, H.T. (1966) "Financial Development and Economic Growth in Underdeveloped Countries", Economic Development and Cultural Change, Vol.14, No.2, p.174-189.

Ünalmış, D. (2002) "The Causality between Financial Development and Economic Growth : The Case of Turkey", Research Department Working Paper, No.3.

$\mathrm{Xu}$, Z. (2000) "Financial Development, Investment and Economic Growth", Economic Inquiry, Vol.38, No.2, p.331-344.

Yücel, F. (2009) "Temel Bileşenler Yöntemiyle Türk Sermaye Piyasası Gelişiminin Ekonomik Büyüme Üzerine Etkilerinin Analizi”, Vol.9, No.9, p.77-86. 
